\title{
MUNICIPAL POLICE AND ORGANIZED CRIME. THE CASE OF MICHOACÁN, MEXICO
}

\section{Jerjes Izcoatl Aguirre Ochoa'}

Hugo Amador Herrera Torres ${ }^{2}$

\begin{abstract}
This article analyzes the functions performed by municipal police to contain criminal activity in the state of Michoacán, Mexico; specifically in the 'Hotlands' (Tierra Caliente) in the 2000-2017 period. Using an ethnographic approach based on 35 in-depth interviews with key figures at the municipal level, we found that the police have been unable to control the advance of criminal activity. To make matters worse, there are cases in which they have become allies of delinquent groups. The lack of legitimacy of the police explains to a large extent their inefficiency. The study suggests that the only way out of the crisis of legitimacy facing municipal police forces is to strengthen the rule-of-law, consolidate democratic structures, and have the police adopt the role of mediators in social conflicts. Implementing structural solutions designed to improve the functioning of police in Mexico also demands enhancing the quality of the country's democracy at the municipal level.
\end{abstract}

Keywords: Mexico, Michoacán, Police, Legitimacy

\section{Introduction}

In recent years, Mexico has suffered through a period of violence triggered by the activity of organized crime groups, mostly linked to drug-trafficking. Since 2006, when President Felipe Calderón initiated his strategy to combat organized crime, over 70,000 deaths have been recorded, revealing a

\footnotetext{
${ }^{1}$ El Doctor Jerjes Aguirre Ochoa es Investigador de Tiempo completo con especialidad en sociología del crimen. Tiene estudios de Doctorado en la Universidad Nacional Autónoma de México (UNAM) y el Instituto Tecnológico Autónomo de México (ITAM). Ha publicado mas de 20 libros en revistas de arbitraje estricto, ademas de mas 10 libros. Han realizado diversos proyectos de investigación con financiamiento externo y diversas actividades de vinculación como asesorías a entidades gubernamentales y publicas. Es miembro del Sistema Nacional de Investigadores desde 2003 y revisor editorial de diversas publicaciones internacionales. Universidad Michoacana de San Nicolás de Hidalgo. México. E-mail: jerjes_99@yahoo.com

2 Profesor e investigador de tiempo completo en la Facultad de Economía de la UMSNH, miembro del Sistema Nacional de Investigadores del Consejo Nacional de Ciencia y Tecnología (México), tiene Perfil Deseable PROMEP (SEP), miembro del Sistema Estatal de Investigadores del Consejo Estatal de Ciencia, Tecnología e Innovación del Estado de Michoacán, responsable de cuerpo académico sobre políticas de desarrollo (en consolidación), y cursa el Doctorado en Economía en la Universidad Autónoma de Madrid. Universidad Michoacana de San Nicolás de Hidalgo. México. E-mail: dondurito05@yahoo.com.mx
} 
scenario similar to a civil war (Ángel, 2018). In the United States, meanwhile, the scourge of drug abuse continues unchecked, as does its consequence: more and more deaths by overdose (Center for Disease Control and Prevention, 2018). However, both countries' efforts to reduce drug-trafficking and violence have not worked.

The state of Michoacán, with its long history as an important cannabis-producing territory, is the headquarters for the main criminals groups operating in Mexico. In fact, the most influential cartel today -Jalisco Nueva Generation- has its roots there (Ferrer, 2015). Michoacán was a hotspot of civil uprisings that confronted criminals groups, and provides a proven case of collusion between authorities and delinquent organizations (Riva Palacio, 2014). It can thus serve as a microcosm of the political and economic contradictions that lie behind the phenomenon of criminality in Mexico.

Police forces are the most visible and immediate expression of government, but in Mexico they also symbolize governmental corruption and inefficiency due to their inability to be transformed into effective instruments of law enforcement. To the contrary, they are one of the factors that have exacerbated the crime wave that ravages the country. In 2016, Mexican police were evaluated on their capacity, processes, legitimacy and results. Findings placed them on the lowest level of a worldwide scale, above only Kenya and Nigeria (Mora, 2017). While authorities there have made efforts to professionalize the police, intensified training, raised salaries and established academies, results have fallen far short of expectations in relation to both citizen confidence in those corporations and reducing crime. While many factors may be involved, one key cause is the presence of substantive institutional problems.

Hence, our study set out to analyze the role that Mexico's police have played in the process of battling criminals groups, based on observations of the activities of state and municipal police in Michoacán, where these two levels have proven incapable of controlling criminality or performing activities that effectively contain criminal activity. Worse yet, the police have often become allies of criminal groups (Mora, 2017; El Universal, 2018; Animal político, 2014a; CuartoPoder, 2017; AFP, 2014; Excelsior 2014). We adopted an ethnographic focus as the main research method to analyze the 2000-2017 period based on 35 in-depth interviews with key actors selected in basis its presence on local society: local politicians, journalists, business leaders and academics in six municipalities in the 
'Hotlands' of Michoacán, Apatzingán, Múgica, Uruapan, Coalcomán, Tepalcatepec and Aguililla, all of which are well-known areas of intense organized crime activity (Arteta, 2018; 24 Horas, 2018).

The interviews lasted around an hour and were scheduled in advance with interviewees with the stated aim of discussing aspects of municipal dynamics. For reasons of security, we did not specify the purpose of the interviews so as not to bias results. In addition to the interviews, we spoke with local and state police officers and attended official events involving security forces, such as conventions and informative community meetings. All interviews were held during the first semester of 2018.

\section{The state, police and legitimacy}

Our approach assumed that Mexico's police cannot become efficacious law enforcement corporations as long as the State fails to take substantial steps towards constructing greater legitimacy and establishing the rule of law. Obviously, police forces constitute a sub-system of the Mexican State that, simply put, is not functioning in the interests of citizens, but this is a consequence of a political system that, in general, faces severe problems of legitimacy and a weak representative democracy.

The case of Michoacán reveals the contradictions of an incipient democracy that has not achieved a level of representativeness that would imbue police with the strength required to enforce the law or the ability to exercise its monopoly on the use of force. Hence, a structural solution to the problem of police requires extensive improvements in government legitimacy and the systems that administer justice, as well as more involvement by society in building efficient, efficacious corporations. The fact that the State lacks legitimacy among citizens is reflected in the mistrust manifested towards police (Punch, 200). In Michoacán, police actions are seen as repressing people's freedom and elements of conspiracies by political authorities that target them.

The police thus reproduce the problems of legitimacy of the Mexican State. According to the World Internal Security and Police Index (WISPI; Abdelmottlep, 2016), Mexico is one of five countries where police have the least legitimacy. Thus, the concept of legitimacy can provide a starting point for explaining the deterioration of the police, for it is a fundamental aspect of all governments. Lamb (2015) argues that legitimacy is an attribute that emerges in a specific population where it is ascribed to a particular object -like a government or State- that satisfies certain criteria which make it 
worthy of loyalty or support. Legitimacy can be measured in terms of concepts like consent, law, tradition, leadership, efficacy and norms. Levin, Sacks and Tyler (2009) sustain that legitimacy is based on two anteceding conditions: government reliability and processual justice, which are evidenced when citizens show a willingness to obey the police and courts. Habermas (1976) writes that legitimacy means the existence of sufficient arguments for a political order that claims to be recognized as just; that is, a legitimate order that merits recognition. Legitimacy is thus a debatable claim to validity, since the stability of any order of domination depends on de facto recognition. Currently, Mexico is living a crisis of legitimacy (García, 2011; Romero, Verhage and Damme, 2009) illustrated by the reality that its citizens feel little moral or rational obligation to obey law and State.

Following Tyler (2004), the legitimacy of police forces depends on the idea that citizens believe they are empowered to serve them, enforce the law, and combat crime. Only then will people recognize and accept a moral obligation to cooperate and behave reciprocally towards those authorities. Without legitimacy, police depend mostly on their faculty to use force, so legitimacy leads to a positive relation with citizens (Mora, 2017). Our study adopts an integrated perspective regarding police legitimacy: it is true that the relation between police and legitimacy has been amply studied, yet no universal concept of legitimacy exists (Noppe, 2017). Generally-speaking, the basis of legitimacy holds that public affairs are evaluated from the perspective of citizens.

\section{The police in state and municipal dynamics}

The dynamics of police in Michoacán, and most places in Mexico, cannot be understood without considering the 60-plus years (1926-2000) that the nation was controlled by a single political party: the Partido Revolucionario Institucional (PRI, Institutional Revolutionary Party) led by the central figure of the President of the Republic who ruled as a virtual six-year emperor who had the authority to name congressmen, appoint members to the judicial branch, determine the composition of state congresses, control businessmen, and censure the press, among many other privileges of power. Those prerogatives were enabled by the PRI's monopoly of political control, which also gave the President the meta-constitutional power to name state governors who, in reality, functioned as 'viceroys' of his central power at the state level. 
Michoacán was no exception to this pattern, in which most governors during PRI domination replicated the function of acting as viceroys of presidential power. In that context, both the police and the organs of justice in the states answered directly to the governor in turn. Meanwhile, the members of the PRI and the governor's friends and business partners usually enjoyed broad indulgences in their dealings with the law and police. In contrast, the political opposition was rigidly subjected to the law and expeditious police action.

The absence of checks and balances, coupled with the enormous vertical power that this presidential system granted to governors, gave police a certain level of efficacy in their labors, but this involved torture, arbitrary detentions and a total disregard for legal procedures that left state police ample maneuvering room to resolve cases involving government interests. This complete control of the organs of justice ensured that, whenever necessary, police officers would enjoy impunity for the abuses they committed against citizens. People's imaginary of that period of single-party rule helped consolidate the perception that police function as a convenient and efficacious extension of the socalled 'political class', which had little regard for citizens or interest in enforcing the law.

Formally-speaking, police forces in Michoacán are divided into state and municipal levels that answer to the state and municipal governments, respectively, with another that depends directly on the office of the state General Procurator of Justice. At the local level, municipal police depend on the municipal president (alcalde or mayor), while state forces answer to the Procurator's office. Another group -the ministerial or "judicial" police- answers directly to the state governor. Municipal police are entrusted with maintaining security at the local level.

Municipal, or local, governments in Mexico are elected for three years and cannot be reelected. ${ }^{3}$ Obviously, this is the level of government closest to citizens' needs, but municipal governments (ayuntamientos) have always been plagued by problems of scarce resources, little professionalization of teams of local public servants, and dependence on federal and state budgets. The only resources they gather on their own come from property taxes and payment for granting permits and licenses to small businesses.

\footnotetext{
${ }^{3}$ In 2018 , this law was modified to allow mayors to be re-elected for two consecutive periods.
} 
Due to the shortage of resources and low level of professionalization, virtually any citizen can serve as a municipal police officer though she/he lacks training, preparation and aptitude for this work. Upon taking office, new mayors organize the municipal police on their own criteria. State police operate in similar conditions; the only significant difference being the 6-year terms in office assigned to governors. During that time, police have virtually complete job security, but the common denominators of police groups are little training, low pay, the absence of a concept of 'careers' in civil or public service, and inefficacy in enforcing the law. Governments at both levels also lack the resources necessary to pay police adequately or establish the institutional structures required to generate careers in public service.

Another aspect is the lack of interest in organizing genuinely independent police forces. As mentioned above, the ministerial (judicial) police answered to the state Procurator, but this official was appointed directly by the governor so, in effect, governors controlled two corporations: the state and ministerial police. This control over law enforcement gave governors and mayors powerful tools for controlling citizens. State Procurators (named and controlled by governors) directed the work of investigative groups that, therefore, acted essentially as political police. As a result, the administration of justice was discretional and depended on the political and personal circumstances of individual governors.

One aspect of all police forces was their inefficiency in containing crime. Society in general was cognizant of the fact that they only acted as a function of the interests of one politician or another, so none of the three levels - municipal, state, judicial- enjoyed legitimacy in the eyes of citizens. Rather, they were seen as corrupt servants of the political class. The fact that the political system is rife with corruption, coupled with the weak rule of law generated and institutionalized a whole series of informal practices including, for instance, the bribes (mordidas) offered to police at all three levels to resolve all manner of criminal acts. Citizens knew that the police would rarely investigate cases if no mordida were forthcoming. In reality, any problem could be settled easily and quickly by bribing the police; another practice that reveals the politicized nature of police forces in society (Mejía, Vargas and Pérez, 1966).

Democratic alternation in the presidency -which began in Mexico in 2000 and affected most states- has failed to produce an authentic state democracy marked by a system of checks-and-balances, 
clearly-defined responsibilities of governors, and instruments of transparency focused on the use of public resources. Governors still ruled as six-year kings and maintain control over the means of communication, the legislative branch and judicial power, but were now free of one counterweight: the President. The positive changes that emerged in federal Executive Power seem not to apply to governors. At the Federal level, legislative power has been exercised effectively as a counterweight to the President, while in the same period, the press and communications media expanded their roles to criticize the Executive in support of an emerging system of counterweights. In individual states, however, this rarely occurred.

During the six-year term of governor Lázaro Cárdenas Batel (2000-2006) in Michoacán -the first non-PRI governor ever elected- no substantive changes designed to improve the quality of democracy of state or municipal governments occurred. Cárdenas' government did carry out some public works, but no significant improvements occurred in healthcare, education or economic development. The discretional power granted to governor's to manage state budgets allowed them to control the communications media and strengthen control over congressmen in state legislatures. The judicial branch did not enjoy more independence, and the organs that administer justice were unable to appoint independent prosecutors in key areas, much less to combat corruption. Although some autonomous organs were established to improve transparency in access to government information and human rights, they were weak in character, and could only issue recommendations that had no practical effects. They could not impose sanctions of any kind. Thus, the democratic transition in Michoacán did not translate into a strengthening of democratic mechanisms; rather, the new governments turned existing control structures to their own benefit including, of course, the police.

The few noteworthy efforts made to date include creating a Police Academy and establishing an office that, supposedly, coordinates municipal police forces and provides training and brief professional development courses, in addition to keeping an inventory of the weapons used by police. However, no significant changes occurred in the structure of state and municipal police, as municipal forces served during the 3-year period of local government, and state corporations for the governors' 6 -year term. State governments generally showed little willingness providing sufficient resources to the police because in contexts of tight budget restrictions public security was not deemed a priority. 
In ensuing state governments, police were used discretionally, based on purely political criteria, to contain social problems in many areas of Michoacán; for example, disputes over land tenure in indigenous zones (Gochi, 2017), and the activities of labor unions. At the same time, however, and also due to clearly political considerations, student groups were allowed to block highways and railways with no police intervention (Casimiro, 2018; Estrada, 2018).

This discretional use of police, performed with little regard for the juridical frameworks that existed to regulate the use of public force, only increased the citizenry's mistrust and accentuated the perspective that police operate to defend the interests of political elites. The result was that no police force was equipped to confront the emergence of criminals groups in Michoacán, like the Caballeros Templarios (Templar Knights), who by 2004 were dominating broad aspects of the political, economic and social life in Michoacán through extortion, while participating actively in local politics.

The state and municipal police should have been the first line of defense against such criminal activity. Local police soon became aware of the dimensions of organized delinquency in their municipalities and the informal rule they imposed on various sectors of society, but being subject to the structure of local government they often became allies of criminal groups. Many candidates for positions as mayor forged alliances with criminal groups in order to win election thanks to the resources they provided and their ability to intimidate rival politicians (Proceso, 2009; Fernández, 2016; Jiménez, 2018).

Thus the police, virtually bereft of autonomy, independence, professionalization and logistical capacity, became one more gear in a system of corruption and collusion with criminals. Worse yet, the organizational and administrative climate in which state and municipal police operate in Michoacán is unacceptable, for it is characterized by job insecurity, extenuating hours, poor salaries, and the everpresent reality of being killed in the line of duty (Animal Politico, 2018; 2013, 2014b; Sierra, 2016). Finally, the police lack an adequate doctrinal formation that would inculcate the importance of their work for the wellbeing of society as a whole.

\section{Results}


The results of our interviews clearly manifest people's mistrust of the police as an organ law enforcement entrusted with maintaining peaceful social co-existence. Almost unanimously, interviewees said that "the police are just as corrupt as [politicians], anything involving them can be resolved with a bribe, that's just how things work". Also, they often mentioned the police's inability to prevent or investigate crimes: "robberies and shootings happen around here all the time [but] when you call the police they're always too late... we've never seen them arrest anybody".

Most interviewees were still highly-aware of terrible acts of violence that they experienced during the period of domination of the Templar Knights, including extortion, murder and kidnapping, but they also remember that as part of their operations criminal groups worked to guarantee peace and security: "if you had some problem you'd go to the local boss (jefecillo) of the Templars and he'd take care of it. They punished men who beat their wives, thieves and crystal-dealers".

The social support and approval that criminal groups in Michoacán achieved was due, precisely, to the trust or confidence they were able to generate initially among many citizens through their selfproclaimed role as authentic defenders of societal values. To a great degree, the legitimacy that should have accrued to State and, more specifically, local governments, was instead garnered by criminal groups. Our interviewees stated: "local politicians began to approach criminal groups because they saw how they were dealing with people. They felt it was good and normal to approach them 'cause they were doing lots of good for people; we had a problem with a group of teachers at a school here that was resolved when 'xxx' intervened and set everything right; so all the candidates went looking for the bad guys."

The people we interviewed pointed out some "positive" features of criminals: "when they were around there were almost no drug-dealers, and robberies went down; they imposed more order than the police we have now"; adding that most elected mayors had some kind of informal agreement with delinquent groups: "sometimes you can't tell the difference between the bad guys and those who govern; everybody knows that mayor 'xxx' negotiated with delinquents to take power [and] sent them to beat up his rival; well, that's what people say, anyway". Other comments indicated that municipal police officers served as mayors' armed guards, always ready to threaten citizens: "when problems arose the 'Presi' (mayor) sent the municipal police to do something to you... they often spent their shifts watching over the mayor's parties and ranches". 
The police officers we interviewed were aware of citizen's dismal view, but they see themselves as poorly-trained, poorly-paid men and women, forced to work in deplorable conditions: "most of society sees us as the bad guys of the movie; they don't realize that we have families too and work 24hour shifts with only 12 hours to rest. We don't get paid overtime and often don't receive all the benefits (prestaciones) marked by law, and we always risk our lives at work". When questioned about the relation between political power and their work, they commented: "we just do our job, we have commanders and chiefs we have to obey; we don't get involved in politics or nothing to do with elections or [political] parties".

On the topic of legitimacy, our interviewees said that "nobody respects the police... sometimes they're afraid to enforce the law, or arrest somebody without knowing he's a friend of some politician, so they have to let him go; sometimes when they detain a guy the family runs out to defend him, especially women, so the police can't do anything".

\section{Conclusions}

Michoacán reflects to a significant degree the situation of political instability and lack of institutional consolidation that people live on a daily basis in Mexico. The country's democratic transition has failed to generate sufficient trust and legitimacy in state and municipal governments among citizens. In particular, the level of government that presents the severest problems of legitimacy is the local one which, in turn, produces vacuums of authority in police forces (the first defense against criminality).

The results of our research demonstrate the negative perception that citizens hold in relation to the association between the political class and police. Similarly, people express deep inconformity with the performance of police forces and, in general, the entire apparatus of government, as can be seen in the low scores they give to the police as representatives of government. These findings reveal the need for substantive changes in citizens' perceptions of government and police. But is it possible to create an efficient police force in a context in which democratic and political consolidation are lacking?

This study further suggests the need to articulate the battle against organized crime with a political and social perspective that goes beyond the utilization of police- and army-based measures. The consolidation of criminal groups in Michoacán was a consequence of a complex process of social 
decomposition and institutional vacuums that organized crime groups were happy to step in and fill. The police have shown themselves to be not only totally inefficient but even active participants in this process of decomposition that has left the playing field open to the operations of delinquent groups.

Attacking the problem of the police in Mexico clearly requires consolidating the institutions that regulate social behavior, strengthening the rule of law, and re-thinking the structure of basic political units, including the municipality. As long as local and state governments remain corrupt and inefficient, their wing entrusted with enforcing the law can be no different.

In 2017, the government attempted to resolve the problems of the inefficiency of municipal police forces by centralizing control of the police in state governments. In this program -called 'Single Command' (Mando Único)- the federal government encouraged states to adopt a model conceived to concentrate municipal forces under state authority, based on the assumption that this would lead to better coordination among the different units of municipal police, while shielding them from corruption. But this approach also presupposed that state corporations function adequately, which is clearly not the case; nor is it true that centralizing police functions results in greater coordination (Mora, 2017). In Michoacán, where there is irrefutable evidence of the collusion of police forces with organized crime, the 'Single Command' only served to further institutionalize organized crime groups (Mora, 2017). Once installed, the program did little to significantly reduce crime rates or levels of insecurity. In fact, it generated inconformity in many municipal governments, which considered it an intromission into their space of authority by police from the state capital. This confirms the existence of severe problems in the police forces that still represent corrupt and inefficient state authorities.

\section{POLICÍA MUNICIPAL Y DELITO ORGANIZADO. EL CASO DE MICHOACÁN, MÉXICO}

\section{Resumen}

En el artículo se analiza la función de contención de la actividad criminal por parte de las policías municipales del estado de Michoacán, en específico, de la zona de Tierra Caliente, para el periodo 2000-2017. A través de un enfoque etnográfico compuesto por 35 entrevistas a profundidad a personajes claves en los municipios, se encontró que las policías han sido incapaces de controlar el avance de la actividad criminal; peor aún, que las policías se convirtieron en aliados de los grupos delincuenciales. La falta de legitimidad de la policía explica en buena medida su ineficiencia. El trabajo sugiere que la salida a la crisis de legitimidad de las policías municipales se hallan en el fortalecimiento del Estado de Derecho, avanzar en esquemas democráticos, y adoptar por parte de la policía, una 
posición mediadora inicial en los conflictos sociales. Las soluciones estructurales del funcionamiento policial en México se encuentran en mejorar la calidad democrática a nivel municipal.

Palabras clave: México, Michoacán, Policía, Legitimidad.

\section{Bibliography}

ABDELMOTTLEP, M. World Internal Security and Police Index International, 2016. Florida, USA: International Science Association IPSA.

AFP. "Caen 8 policías de Michoacán por presuntos nexos con crimen”. 2014. Milenio. Accessed at: http://www.milenio.com/policia/caen-8-policias-michoacan-presuntos-nexos-crimen

ÁNGEL, A. "Homicidios repuntan en marzo: asesinatos en gobierno de Peña Nieto ya superan los que hubo con Calderón". 2018. Animal político. Accessed at: https://www.animalpolitico.com/2018/04/homicidios-repuntan-marzo-government-epn/

ANIMAL POLÍTICO. "Presidente municipal michoacano está coludido con criminales, acusan purépechas". 2013. Animal Político. Accessed at: https://www.animalpolitico.com/2013/07/presidentemunicipal-michoacano-esta-coludido-con-criminales-acusan-purepechas/

ANIMAL POLÍTICO. "Detienen a 14 policías en Michoacán por presuntos nexos con el narco". 2014. Animal politico. Accessed at: https://www.animalpolitico.com/2011/02/detienen-a-14-policias-enmichoacan-por-presuntos-nexos-con-el-narco/

ANIMAL POLÍTICO. "Matan a director de Seguridad Pública en Michoacán; investigan a policías municipales". 2014. Animal Político. Accessed at: https://www.animalpolitico.com/2014/05/ejecutanal-director-de-seguridad-publica-de-alvar-obregon-investigan-policias-municipales/

ANIMAL POLÍTICO. "Matan a cuatro policías auxiliares en Michoacán; sus cuerpos tenían huellas de tortura”. 2018. Animal Político. Accessed at: https://www.animalpolitico.com/2018/06/matan-policiasmichoacan/

ARTETA, I. "El crimen organizado impone sus reglas a los candidatos en Tierra Caliente, Guerrero". 2018. Animal Político. Accessed at: https://www.animalpolitico.com/2018/06/guerrero-candidatoscrimen-organizado/

CASIMIRO, N. "Normalistas asaltan, secuestran y saquean camiones en Tiripetío". A tiempo. 2018. Accessed at: https://www.atiempo.mx/denuncias/normalistas-asaltan-secuestran-y-saquean-camionesen-tiripetio/ 
CENTER FOR DISEASE CONTROL AND PREVENTION. "U.S. drug overdose deaths continue to rise; increase fueled by synthetic opioids". 2018. CDC Newsroom. Accessed at: https://www.cdc.gov/media/releases/2018/p0329-drug-overdose-deaths.html

CUARTO PODER. "Detienen a 45 policías de Tingambato y Ziracuaretiro por nexos con el narco". 2017. CuartoPoder. Accessed at:

https://cuartopodermichoacan.com/detienen-a-45-policias-de-tingambato-y-ziracuaretiro-por-nexoscon-el-narco/

EL UNIVERSAL. "Detienen a 30 policías de Ocampo por presuntos nexos con criminales". 2018. El siglo de Durango. Accessed at:

https://www.elsiglodedurango.com.mx/noticia/972812.detienen-a-30-policias-de-ocampo-porpresuntos-nexos-con-criminales.html

ESTRADA, A. "Secretaría de Educación de Michoacán con daños tras "toma" de la CNTE". El financiero. 2018. Accessed at:

http://www.elfinanciero.com.mx/nacional/secretaria-de-educacion-de-michoacan-con-danos-trastoma-de-la-cnte

EXCELSIOR. “Suman 150 policías detenidos en Michoacán por nexos con el crimen”. 2014. Excelsior. Accessed at: https://www.excelsior.com.mx/nacional/2014/10/28/989317

FERNÁNDEZ, J. “Así trabajan los alcaldes del narco". 2016. Periódico Debate. Accessed at: https:/www.debate.com.mx/opinion/Asi-trabajan-los-alcaldes-del-narco-20160804-0011.html FERRER, M. “Cártel Jalisco Nueva Generación: el nuevo imperio del narco”. 2015. Reporte Índigo. Accessed at: https://www.reporteindigo.com/reporte/cartel-jalisco-nueva-generacion-el-nuevoimperio-del-narco/

GARCÍA, V. “¿Crisis de legitimidad en la representación política? Consideraciones sociológicas para una nueva forma de democracia". XII Certamen de Ensayo Político. 2011. Monterrey, NL: Comisión Estatal Electoral de Nuevo León. Accessed at:

https://www.ceenl.mx/educacion/certamen_ensayo/doceavo/4MH.\%20\%C2\%BFCrisis\%20de\%20leg itimidad\%20en\%201a\%20representaci\%C3\%B3n\%20pol\%C3\%ADtica.pdf

GOCHI, L. Enfrentamiento en la Meseta Purépecha deja muertos y heridos. 2017. Provincia, Accessed at:

http://www.provincia.com.mx/web/Enfrentamiento_en_la_Meseta_Pur\%C3\%A9pecha_deja_deaths_ y_heridos-69389

HABERMAS, J. La reconstrucción del materialismo histórico. 1976. Madrid: Taurus. 
JIMÉNEZ, L. "Pagará ex alcalde de Álvaro Obregón por asesinar a 10 jóvenes". 2018. Primera Plana Noticias. Accessed at:

https://primeraplananoticias.mx/portal/pagara-ex-alcalde-de-alvaro-obregon-por-asesinar-a-10jovenes/

LAMB, R. Measuring Legitimacy in Weak States. 2015. Maryland: Center for International and Security Studies at Maryland.

LEVIN M., A. Sacks and T. Tyler. "Conceptualizing Legitimacy, Measuring Legitimating Beliefs". 2009. American Behavioral Science, Vol. 53, issue 3, pp: 354-375.

NOPPE J., A. Verhage and A. Damme. "Police legitimacy: an introduction". Policing: An International Journal, 2017, Vol. 40, issue 3, pp. 474-479. Accessed at: https://doi.org/10.1108/PIJPSM-05-20170058

MEJÍA, A., E. Vargas and M. Pérez. "Michoacán ¿feudo cardenista? Historia de una lucha estudiantil vencida con la traición y el asesinato", 1966. Mexico: Editorial Nuevos Caminos.

MORA, F. "Sin legitimidad no hay policía". 2017. Nexos. Accessed at: https://seguridad.nexos.com.mx/?p=167

PROCESO. "Coludidos con el narco, alcaldes y diputados locales de Michoacán: Coparmex”. 2009. Proceso. Accessed at:

https://www.proceso.com.mx/114024/coludidos-con-el-narco-alcaldes-y-diputados-locales-demichoacan-coparmex

PUNCH, M. "Police Corruption and its Prevention". 2000. European Journal of Criminal Policy and Research, Vol. 8, pp. 301-324.

RIVA PALACIO, R. "Michoacán, ejemplo de narco Estado". 2014. El financiero. Accessed at: http://www.elfinanciero.com.mx/opinion/raymundo-riva-palacio/michoacan-ejemplo-de-narco-estado ROMERO, R. "Sobre la crisis de legitimidad del sistema político mexicano: notas para un nuevo acuerdo". 2009. Andamios, 6(11), pp. 369-373. Accessed at:

http://www.scielo.org.mx/scielo.php?script=sci_arttext\&pid=S1870-

$00632009000200017 \& \operatorname{lng}=\mathrm{es} \& \ln \mathrm{ln}=\mathrm{es}$

SIERRA, C. "Van 12 emboscadas a policía en Michoacán: 8 muertos y 12 lesionados". 2016. Quadratin. Accessed at:

https://www.quadratin.com.mx/principal/van-12-emboscadas-a-policias-en-michoacan-8-muertos-12lesionados/ 
TYLER, T. "Enhancing Police Legitimacy". 2004. The ANNALS of the American Academy of Political and Social Science, 593, pp. 84-98.

24 HORAS. "Organized crime realiza bloqueos y quemas en Tierra Caliente de Michoacán”. 2018. 24 horas. El diario sin limites. Accessed at:

http://www.24-horas.mx/2018/03/14/crimen-organizado-realiza-bloqueos-quemas-en-tierra-calientemichoacan/

Trabalho recebido em 18 de janeiro de 2018 Aceito em 14 de fevereiro de 2019 